\title{
Efektivitas Strategi Think Talk Write terhadap Kemampuan Pemecahan Masalah Matematis Siswa
}

\author{
Indri Cahyaningrum ${ }^{1}$, Asmaul Husna ${ }^{1, a)}$, Yesi Gusmania ${ }^{1}$ \\ ${ }^{I}$ Universitas Riau Kepulauan \\ Jl. Pahlawan No. 99 Bukit Tempayan, Batu Aji, Batam, Kepulauan Riau, Indonesia, 29424 \\ a)asmaul_uul25@yahoo.com
}

\begin{abstract}
The purpose of this research is to test effectivity strategy Think Talk Write (TTW) of the ability of problem solving mathematical, and test whether the differences efektivity between strategy Think Talk Write (TTW) with determine saintific of the ability of problem solving mathematical students. The kind of research this quasi his experiments with design research posttest only control group design. Population in research it is a whole students grade VIII of SMP Negeri 34 Batam which consisted of 279 students which are divided into 7 class. echnique the sample researchers used was purposive sampling, where samples selected on a consideration of the principal and math teacher and chosen class VIII G as a class experiment and class VIII E as a class control with 39 students in each class. An instrument used research it will be a test the discussion as much as 4 about that has been tested validitas, reliability, the standart hardship and capacity classification. Based on researchers sig.(2tailed) $=0.028<0.05$ and sig. $(2$-tailed $) 0.013<0.05$. So that can be concluded Think Talk Write (TTW) effective in the ability of problem solving mathematical students and there is a difference effectivity between strategy Think Talk Write (TTW) with determine saintific of the ability of problem solving mathematical students.
\end{abstract}

Keywords: learning strategy; think talk write; problem solving skill

\begin{abstract}
Abstrak. Tujuan penelitian ini adalah untuk menguji keefektivan Strategi Think Talk Write (TTW) terhadap kemampuan pemecahan masalah matematis, dan menguji perbedaan keefektifan antara Strategi Think Talk Write (TTW) dengan pendekatan saintifik terhadap kemampuan pemecahan masalah matematis siswa. Jenis penelitian ini quasi eksperimen dengan design penelitian posttest only control group design. Populasi dalam penelitian ini adalah seluruh siswa kelas VIII SMP Negeri 34 Batam yang berjumlah 279 siswa yang terbagi atas 7 kelas. Teknik pengambilan sampel yang peneliti gunakan adalah purposive sampling, dimana sampel yang dipilih berdasarkan pertimbangan dari kepala sekolah dan guru matematika maka dipilih kelas VIII G sebagai kelas eksperimen dan kelas VIII E sebagai kelas kontrol dengan siswa masing-masing 39. Instrumen yang digunakan penelitian ini berupa tes uraian sebanyak 4 soal yang telah diuji validitasnya, reliabilitas, tingkat kesukaran dan daya pembedanya. Berdasarkan hasil penelitian nilai sig. $(2$-tailed $)=0.028<0.05$ dan sig. $(2$-tailed $)=0.013<$ 0.05. Sehingga dapat disimpulkan strategi Think Talk Write (TTW) efektif terhadap kemampuan pemecahan masalah matematis siswa dan terdapat perbedaan keefektifan antara Strategi Think Talk Write (TTW) dengan pendekatan saintifik terhadap kemampuan pemecahan masalah matematis siswa.
\end{abstract}

Kata kunci: strategi pembelajaran; think talk write (TTW); kemampuan pemecahan masalah

Available online at journal homepage: 


\section{PENDAHULUAN}

Pendidikan formal, salah satu mata pelajaran di sekolah yang dapat digunakan untuk membangun cara berfikir siswa adalah matematika. Oleh karena itu, pelajaran matematika di sekolah tidak hanya menekankan pada pemberian rumus-rumus, melainkan juga mengajarkan siswa untuk dapat menyelesaikan berbagai masalah matematis yang berkaitan dengan kehidupan sehari-hari. Selain itu pelajaran matematika di sekolah diharapkan mampu membuat siswa memandang matematika sebagai sesuatu yang dapat dipahami, merasakan matematika sebagai sesuatu yang berguna, dan meyakini usaha yang tekun dan ulet dalam mempelajari matematika akan membuahkan hasil. Banyak hal yang diharapkan dapat diperoleh siswa dengan belajar matematika. Salah satu diantaranya adalah kemampuan pemecahan masalah matematis. Kemampuan pemecahan masalah matematis merupakan aspek kognitif yang sangat penting, salah satu diantaranya siswa dapat berfikir kritis. Siswa dituntut untuk menggunakan segala pengetahuan yang diperolehnya untuk dapat memecahkan suatu masalah matematika.

Berdasarkan observasi di SMP Negeri 34 Batam diperoleh informasi bahwa proses pembelajarannya dengan pendekatan saintifik, namun dalam proses pembelajaran matematika masih ditemukan permasalahan. Salah satu masalah yang dihadapi adalah rendahnya kemampuan pemecahan masalah matematis siswa, sehingga menjadi salah satu penyebab rendahnya rata-rata hasil belajar matematika siswa kelas VIII di SMP Negeri 34 Batam. Nilai rata-rata ujian semester ganjil siswa banyak yang belum memenuhi Kriteria Ketuntasan Minimum (KKM) yang ditetapkan sekolah, dengan (KKM) untuk mata pelajaran matematika adalah 74.

Hasil wawancara pada 3 Maret 2018 dengan dua guru matematika diperoleh informasi bahwa guru telah berupaya untuk meningkatkan hasil belajar matematika siswa dengan berbagai cara, diantaranya mengulang materi yang belum dimengerti, menjelaskan soal pemecahan masalah dengan mengaitkan kedalam kehidupan sehari-hari, memberikan tambahan latihan, dan memberikan remedial bagi siswa yang belum memenuhi Kriteria Ketuntasan Minimum (KKM). Tapi usaha tersebut belum cukup. Beberapa permasalahan yang sering dihadapi siswa dalam pembelajaran matematika yaitu, siswa belum bisa menyelesaikan soal-soal matematika yang berbeda dari contoh yang diberikan, siswa masih bersikap pasif dalam proses pembelajaran dan masih takut atau malu bertanya pada guru mengenai materi yang kurang dipahami, serta siswa menghafal rumus tetapi tidak bisa mengaplikasikan ke dalam soal sehingga siswa belum bisa menyelesaikan soal ujian, terutama soal berbentuk pemecahan masalah berakibat banyak siswa tidak mencapai KKM.

Berdasarkan permasalahan tersebut dapat disimpulkan bahwa siswa mengalami kesulitan dalam pemecahan masalah matematis. Oleh karena itu pemecahan masalah perlu ditingkatkan pada siswa kelas VIII di SMP Negeri 34 Batam. Salah satu usaha yang bisa guru lakukan antara lain 
adalah memberikan strategi pembelajaran yang tepat dalam pembelajaran matematika. Menurut Suherman (dalam Yanuarta, Waluyo \& Suratno, 2014) Strategi adalah siasat yang sengaja direncanakan oleh guru, berkenaan dengan segala persiapan pembelajaran agar pelaksanaan pembelajaran berjalan dengan lancar dan tujuannya yang berupa hasil belajar bisa tercapai dengan optimal. Strategi yang dirasa cocok untuk diterapkan pada kondisi ini adalah Think Talk Write (TTW), karena mempunyai beberapa karakteristik yaitu (1) melibatkan siswa secara aktif dalam melakukan eksplorasi suatu konsep matematika; (2) mengkonstruksi dengan benar pengetahuan awal siswa baik dari pengalaman maupun informasi yang diterima; (3) termasuk model pelajaran konstruktif yang dilakukan secara kooperatif; (4) Think Talk Write (TTW) dibangun oleh ada kemampuan berpikir, berbicara dan menulis, siswa yang dikelompokkan secara heterogen kemudian diberikan permasalahan untuk dipikirkan, diskusikan dalam kelompok dan kemudian bersama-sama mencari solusi; dan (5) karena terdapat langkah diskusi maka guru dengan mudah mengetahui konsep siswa dan dengan diskusi juga dapat mengarahkan untuk merubah konsepnya.

Yamin dan Ansari (2012) menyatakan bahwa suatu strategi yang diharapkan dapat menumbuh kembangkan kemampuan pemecahan masalah adalah strategi Think Talk Write (TTW). Strategi Think Talk Write (TTW) yang diperkenalkan oleh Huinker \& Laughlin ini pada dasarnya dibangun melalui berfikir (think), berbicara (talk), dan menulis (write). Strategi pembelajaran TTW merupakan strategi yang dimulai dengan alur keterlibatan siswa dalam berfikir (think), berdialog dengan dirinya sendiri setelah proses membaca, selanjutnya berbicara dan membagi ide (sharing) dengan temannya sebelum menulis (Hamdayama, 2015). Suasana seperti ini lebih efektif jika dilakukan dalam kelompok heterogen dengan 3-5 siswa. Dalam kelompok ini siswa diminta membaca, membuat catatan kecil, menjelaskan, mendengarkan dan membagi ide bersama teman kemudian mengungkapkannya melalui tulisan. Dari uraian di atas dapat disimpulkan bahwa strategi pembelajaran Think Talk Write (TTW) adalah suatu strategi pembelajaran dengan alur yang dimulai dari keterlibatan siswa dalam berfikir (think), berbicara/berdiskusi (talk) dan menulis hasil diskusi (write) agar kompetensi yang diharapkan tercapai. Lebih rinci dalam penelitian ini langkahlangkah pembelajaran dengan strategi TTW yang digunakan adalah:

1. Guru membagi siswa dalam kelompok kecil yaitu maksimum 6 siswa.

2. Guru membagikan LKS kepada masing-masing siswa secara berkelompok.

3. Guru memberi ulasan singkat tentang materi yang akan dipelajari.

4. Siswa memahami materi yang ada dalam LKS

5. Siswa membaca masalah yang ada dalam LKS dan membuat catatan kecil secara individu tentang apa yang ia ketahui dan tidak ketahui dalam masalah tersebut. Ketika siswa membuat catatan kecil inilah akan terjadi proses berpikir (think) pada siswa. Setelah itu siswa berusaha untuk meyelesaikan masalah tersebut secara individu. Kegiatan ini bertujuan agar siswa 
dapat membedakan atau menyatukan ide-ide yang terdapat pada bacaan untuk kemudian diterjemahkan ke dalam bahasa sendiri.

6. Siswa berinteraksi dan kolaborasi dengan teman satu grup untuk membahas isi catatan dari hasil catatan (talk). Dalam kegiatan ini mereka menggunakan Bahasa dan kata-kata yang mereka sendiri untuk menyampaikan ide-ide dalam diskusi. Pemahaman dibangun melalui interaksinnya dalam diskusi. Diskusi diharap dapat menghasilkan solusi atas soal yang diberikan.

7. Dari hasil diskusi, siswa secara individu merumuskan pengetahuan berupa jawaban atas soal (berisi landasan dan keterkaitan konsep, metode, dan solusi) dalam bentuk tulisan (write) dengan bahasa mereka sendiri. Pada tulisan itu, Siswa menghubungkan ide-ide yang diperolehnya melalui diskusi

8. Perwakilan kelompok menyajikan hasil diskusi kelompok, sedangkan kelompok lain diminta memberikan tanggapan.

Turmudi (dalam Husna \& Fatimah, 2013) mengatakan bahwa pemecahan masalah matematis adalah proses melibatkan suatu tugas yang metode pemecahannya belum diketahui lebih dahulu. Untuk mengetahui penyelesaiannya siswa hendaknya memetakan pengetahuan mereka, dan melalui proses ini mereka sering mengembangkan pengetahuan baru tentang matematika. Dengan melalui pemecahan masalah dalam matematika siswa hendaknya memperoleh cara-cara berfikir, kebiasaan untuk tekun dan menumbuhkan rasa ingin tahu, serta percaya diri dalam situasi tak mereka kenal yang akan mereka gunakan diluar kelas. Pemecahan masalah merupakan bagian tak terpisahkan dari semua pembelajaran matematika dan hendaknya tidak terisolasi dari program matematika. Adapun indikator pemecahan masalah matematisnya. Dari berbagai pernyataan pemecahan masalah, maka indikator yang akan digunakan peneliti yaitu memahami masalah, merencanakan penyelesaian, menerapkan strategi untuk menyelesaikan berbagai masalah didalam/diluar matematika dan menuliskan hasil jawaban dari permasalahan.

\section{METODE}

Penelitian ini merupakan jenis penelitian eksperimen semu (quasi-eksperimen), dimana rancangan penelitian yang digunakan apabila kontrol tidak sepenuhnya dapat dilakukan, hal ini dikarenakan peneliti tidak meneliti semua variabel bebas yang mempengaruhi variabel terikat di dalam penelitian ini. Penelitian ini menggunakan dua kelompok sampel yaitu kelompok eksperimen dan kelompok kontrol. Kelompok eksperimen adalah kelompok siswa yang memperoleh pembelajaran dengan strategi Think Talk Write sedangkan kelompok kontrol merupakan kelompok siswa yang mengikuti pembelajaran dengan pendekatan saintifik yaitu cara biasa yang digunakan di kelas tersebut, kepada dua kelompok diberikan tes akhir. 
Pada penelitian ini yang menjadi variabel bebas adalah strategi pembelajaran Think Talk Write dan pendekatan saintifik. Pada penelitian ini yang merupakan variabel terikat adalah kemampuan pemecahan masalah matematis siswa setelah diberi perlakuan berupa strategi Think Talk Write dikelas eksperimen dan pendekatan saintifik dikelas kontrol. Pada penelitian ini yang menjadi variabel moderator adalah kemampuan awal siswa.Populasi pada penelitian ini adalah seluruh siswa kelas VIII SMP Negeri 34 Batam Pemilihan sampel penelitian ini dengan purposive sampling, dimana sampel terpilih atas pertimbangan guru dan kepala sekolah. Sehingga terpilih kelas VIII G sebagai kelas eksperimen dan kelas E sebgai kelas kontrol Instrumen yang digunakan adalah tes uraian. Analisis data menggunakan uji-t untuk semua hipotesis. Pengujian hipotesis dibantu dengan Software SPSS Statistics 20.

\section{HASIL DAN PEMBAHASAN}

Analisis data dilakukan untuk mengungkapkan kemampuan pemecahan masalah matematis siswa setelah dilaksanakan strategi pembelajaran Think Talk Write. Berdasarkan perhitungan diketahui bahwa kemampuan pemecahan masalah matematis siswa yang diajar dengan strategi Think Talk Write efektif sedangkan pada kemampuan pemecahan masalah matematis siswa yang diajar dengan pendekatan saintifik menyatakan tidak efektif.

Tabel 1. Hasil Uji Normalitas

\begin{tabular}{ccc}
\hline Kelompok & Signifikansi & Keterangan \\
\hline Kelas G (Eksperimen) & 0.028 & 0,05 \\
Kelas E (Kontrol) & 0.150 & \\
\hline
\end{tabular}

Tabel 1 menunjukkan bahwa pada kelas G (eksperimen) nilai signifikansinya yang diperoleh $0.028<0.05$ maka Ho ditolak. Sehingga dapat disimpulkan bahwa strategi Think Talk Write (TTW) efektif terhadap kemampuan pemecahan masalah matematis siswa kelas VIII SMP Negeri 34 Batam. Pada kelas E (kontrol) nilai signifikansinya yang diperoleh $0.150>0.05$ maka Ho diterima, sehingga dapat disimpulkan bahwa pendekatan saintifik tidak efektif terhadap kemampuan pemecahan masalah matematis siswa kelas VIII SMP Negeri 34 Batam.

Berdasarkan pengamatan, selama belajar dengan strategi pembelajaran TTW siswa lebih aktif belajar, meskipun ketika pertemuan pertama siswa masih terlihat belum terbiasa dalam belajar karena melaksanakan tahap-tahap strategi pembelajaran TTW dimulai dengan strategi Think Talk Write (TTW) peneliti terlebih dahulu memberikan ulasan singkat mengenai materi yang akan dipelajari, kemudian peneliti membagi siswa dalam kelompok kecil yaitu maksimum 6 siswa dalam satu kelompok. Sehingga terbentuk menjadi 7 kelompok dengan bantuan rekomendasi dari guru mata pelajaran matematika dengan tujuan siswa yang berkemampuan tinggi, berkemampuan sedang dan siswa yang berkemampuan rendah dapat terbagi merata pada setiap kelompok. 
Selanjutnya peneliti membagikan LKS kepada masing - masing siswa dan memjelaskan secara garis besar materi yang akan dipelajari serta memberikan pengarahan tentang proses strategi Think Talk Write (TTW) yang akan mereka jalani pada proses pembelajaran. Kemudian pelaksanaan proses strategi Think Talk Write (TTW) yang bermulai dari think yaitu berfikir, dalam proses ini setiap siswa diberi waktu 10 menit dengan tujuan untuk membaca masalah yang ada pada LKS dan membuat catatan kecil tentang apa yang ia ketahui dan ia tidak ketahui pada masalah tersebut, dan memberikan solusi tentang apa yang ia ketahui. Namun kenyataannya pada pertemuan pertama terlihat banyak siswa masih bingung menuliskan ide dalam bentuk catatan kecil diduga kurang terbiasanya siswa menuliskan suatu ide dan jawaban suatu soal dalam bentuk catatan kecil karena siswa baru pertama kali mengenal strategi pembelajaran Think Talk Write (TTW) yang menuntut siswa menuliskan ide jawaban dan pertanyaan yang belum diketahui dalam bentuk catatan kecil.

Siswa cenderung tidak gigih dalam mengerjakan soal LKS. Hal tersebut terlihat ketika siswa merasa kebingungan mengenai apa yang harus mereka tulis dalam bentuk catatan kecil, siswa cenderung putus asa sehingga menuliskan ide jawaban pada catatan kecil kurang lengkap dan kurang terarah. Siswa pada LKS. Kendala yang dialami siswa pada tahap think pertemuan pertama tersebut mempengaruhi aktivitas siswa pada tahap talk, write, dan presentasi. Pada tahap think masih banyak siswa yang mencuri-curi ke tahap talk (diskusi) padahal belum saatnya lanjut ke tahap talk, setelah tahap talk berlangsung selanjutnya ke tahap write. Pada tahap write terjadi kendala dimana waktu untuk tahap talk telah usai masih ada beberapa siswa yang belum rampung menyelesaikan LKS masih saja melakukan tahap talk (berdiskusi) sehingga mengakibatkan peneliti kekurangan waktu untuk tahap presentasi, sehingga tidak semua kelompok bisa mempresentasikan hasil LKS . Hal ini disebabkan bahwa setiap tahap pembelajaran dengan strategi TTW saling berkaitan karena alur kemajuan strategi TTW dimulai dari keterlibatan siswa dalam berpikir atau berdialog dengan dirinya sendiri setelah proses membaca, selanjutnya berbicara (talk) dan membagi ide dengan kelompoknya sebelum menulis (write) (Hamdayama, 2014).

Pertemuan kedua, sebagian siswa masih belum bisa menuliskan ide gagasan dalam bentuk catatan kecil secara lengkap. Siswa terlihat hanya mensketsa gambar limas, dan hanya menuliskan sedikit jawaban mengenai soal LKS . Hal ini besar kemungkinan siswa tidak paham mengenai materi tersebut karena peneliti tidak memberi penjelasan materi terlebih dahulu kepada siswa, dan siswa terlihat kurang antusias dalam mengerjakan LKS tersebut. Pada tahap talk pertemuan kedua, ada sedikit peningkatan dari pertemuan pertama yaitu siswa terlihat sudah berdiskusi sesuai waktu yang ditentukan, mengenai mendiskusikan ide atau kemungkinan jawaban walaupun hanya dengan teman sebangkunya saja atau teman didepannya Pada pertemuan ketiga dan keempat, siswa sudah bisa menuliskan ide kemungkinan jawaban dalam bentuk catatan kecil, walaupun siswa tidak menuliskan ide tersebut secara lengkap Sehingga pada tahap talk, siswa terlihat berdiskusi dengan 
teman kelompoknya untuk mencari jawaban dari berbagai sumber buku. Siswa terlihat antusias pada kegiatan tersebut, besar kemungkinan disebabkan siswa sudah mulai paham dan bisa melakukan aktivitas dengan baik pada tahap think. Siswa mampu menuliskan gagasan-gagasannya dalam bentuk catatan kecil, terlepas dari apakah gagasan tersebut benar atau salah. Pada tahap talk, secara umum terlihat bahwa sebagian besar siswa sudah cukup baik melakukan aktivitas diskusinya. Apabila ada yang belum paham, siswa bertanya kepada anggota kelompoknya maupun kepada guru.

Pada tahap write pertemuan ketiga dan keempat, sebagian besar siswa menuliskan jawaban hasil diskusi secara individu. Sedangkan pada pembelajaran pertemuan pertama dan kedua, masih banyak siswa yang menyontek pekerjaan temannya, mereka belum mampu mengkontruksi pengetahuan barunya dengan bahasa mereka sendiri. Sehingga membuat tahap write kurang optimal pada pertemuan pertama dan kedua. Sedangkan pada pertemuan ketiga dan keempat, tahap write ini berjalan dengan baik dan lancar. Siswa sudah mampu menuliskan kembali hasil diskusi secara individu dan mengkontruksi pengetahuan barunya dengan bahasa mereka sendiri. Pada uraian tersebut pembelajaran dengan strategi Think Talk Write (TTW) yang telah dilakukan oleh peneliti sesuai berdasarkan langkah-langkah pembelajaran yang telah ditetapkan sebelumnya. Kemudian peneliti meminta perwakilan salah satu kelompok untuk mempresentasikan hasil jawaban kedepan kelas dan kelompok lain dimintai tanggapan, apakah hasil jawaban kelompok tersebut sesuai atau ada kelompok lain yang mendapatkan hasil yang berbeda. Jika ada kelompok lain mendapatkan hasil yang berbeda maka tugas peneliti membantu mengarahkan pada jawaban yang lebih tepat serta menjelaskan materi yang kurang mereka pahami.

Strategi Think Talk Write (TTW) diharapkan dapat membantu siswa dalam pembelajaran matematika, serta meningkatkan kemampuan pemecahan masalah matematis siswa (Yamin dan Ansari, 2012). Sedangkan menurut (Hamdayama, 2014) strategi Think Talk Write (TTW) yaitu strategi yang dapat membantu siswa dalam mengkonstruksi pengetahuannya sendiri sehingga pemahaman konsep menjadi lebih baik, serta siswa dapat mendiskusikan hasil pemikirannya dengan temannya sehingga saling membantu dan bertukar pikiran. Hal ini dapat membantu siswa dalam memahami materi.

Daryanto (2013) mengatakan pendekatan saintifik adalah proses pembelajaran yang dirancang sedemikian rupa agar siswa aktif mengkonstrusi konsep, hukum atau prinsip melalui tahapan - tahapan masalah. Pada pertemuan pertama peneliti menjelaskan materi yang akan dipelajari yaitu bangun ruang sisi datar. Kemudian memberikan latihan yang ada pada LKS dan memberikan kesempatan pada siswa untuk mengamati, menanya permasalahan yang ada pada LKS, mengumpulkan informasi dari berbagai sumber, mengolah informasi yang didapat dan mengkomunikasikan. Namun pada proses mengamati hanya beberapa siswa yang melakukan 
pengamatan, sebagian besar siswa sibuk berbicara dan bercanda. Saat guru menanyakan permasalahan pada LKS siswa dikelas hanya diam, kemudian saat diberi kesempatan mengumpulkan dan mengolah informasi masih banyak siswa yang menyontek kepada temannya. Pada proses mengkomunikasikan atau mempresentasikan hasil, peneliti menunjuk salah satu siswa secara acak banyak siswa yang kurang percaya diri dalam menyampaikan hasil jawabannya.

Hari kedua, ketiga dan keempat tetap dengan pendekatan saintifik namun peneliti mengubah suasana belajar, dimana pada hari pertama mereka belajar secara indivudu diubah menjadi berkelompok. Pada hari kedua terdapat sedikit peningkatan dimana beberapa siswa mulai aktif saat menyelesaikan permasalahan pada LKS. Namun tetap ada siswa yang tidak turut aktif dalam menyelesaikan permasalahan pada LKS sehingga pendekatan saintifik tidak efektif terhadap kemampuan pemecahan masalah siswa. Menurut (Musfiqon \& Nurdyansyah, 2015) pelaksanaan pendekatan saintifik setelah berlakunya kurikulum 2013 belum mampu menghasilkan lulusan yang mampu berpikir kritis setara dengan kemampuan anak - anak bangsa lain.

Pada uji hipotesis mencari perbedaan keefektifan strategi Think Talk Write (TTW) dengan pendekatan saintifik terhadap kemampuan pemecahan masalah matematis siswa kelas VIII pada materi bangun ruang sisi datar. Hasil dapat dilihat dari hasil hipotesisnya dimana nilai signifikansi $0.013<\alpha=0.05$ maka Ho ditolak, sehingga dapat disimpulkan bahwa terdapat perbedaan keefektifan strategi Think Talk Write (TTW) dengan pendekatan saintifik terhadap kemampuan pemecahan masalah matematis siswa kelas VIII SMP Negeri 34 Batam. Dikarenakan kurang aktifnya siswa dalam merespon materi yang disampaikan dan kemampuan pemecahan masalah matematis yang rendah terlihat dari hasil posttest pada kelas kontrol yang mendapatkan nilai rata rata dibawah Kriteria Ketuntasan Minimum (KKM) yaitu 71.54 sedangkan kelas eksperimen mendapatkan nilai di atas Kriteria Ketuntasan Minimum (KKM) yaitu 76.92, sehingga dapat disimpulkan strategi Think Talk Write (TTW) lebih efektif dibandingkan pendekatan saintifik terhadap kemampuan pemecahan masalah matematis siswa kelas VIII SMP Negeri 34 pada materi bangun ruang sisi datar.

Tabel 2. Persentase Hasil Pencapaian Posttest Kemampuan Pemecahan Masalah Matematis

\begin{tabular}{clcc}
\hline No. & \multicolumn{1}{c}{ Indikator Pemecahan Masalah } & Kelas Eksperimen & Kelas Kontrol \\
\hline 1. & Memahami masalah & $100 \%$ & $100 \%$ \\
\hline 2. & Rencana penyelesaian strategi pemecahan masalah & $92 \%$ & $86 \%$ \\
\hline 3. & Menerapkan strategi untuk menyelesaikan masalah & $69 \%$ & $61 \%$ \\
\hline 4. & Menuliskan hasil jawaban & $49 \%$ & $46 \%$ \\
\hline
\end{tabular}

Tabel 2 menunjukkan hasil pencapaian posttest kemampuan pemecahan masalah matematis siswa kelas eksperimen pada indikator rencana penyelesaian strategi pemecahan masalah, menerapkan strategi untuk menyelesaikan masalah dan menulis hasil jawaban persentasi ketuntasan 
lebih tinggi dibandingkan kelas kontrol, dengan ini treatment strategi Think Talk Write (TTW) yang telah dilaksanakan pada kelas eksperimen dapat dikatakan efektif. Pada strategi Think Talk Write (TTW) tahap think sangat berpengaruh, karna dari tahap think siswa dapat mengkonstruksi pengetahuannya sendiri dan pada tahap think siswa dapat menyampaikan ide - idenya. Selaras dengan pendapat (Ningsih, 2014) pada hasil penelitiannya mengungkapkan proses pembelajaran dengan strategi Think Talk Write (TTW) menuntut siswa menyampaikan ide-idenya secara lisan dan tulisan. Dengan demikian strategi Think Talk Write (TTW) dapat menjadi solusi untuk meningkatkan kemampuan pemecahan masalah siswa sesuai dengan pendapat (Sopiany \& Hijjah, 2016) yaitu peningkatan kemampuan pemecahan masalah matematis siswa yang pembelajarannya dengan menggunakan strategi Think Talk Write (TTW) lebih baik daripada siswa yang pembelajarannya menggunakan model pembelajaran konvensional yaitu dengan pendekatan saintifik.

\section{KESIMPULAN}

Berdasarkan hasil analisis dan pembahasan diperoleh kesimpulan, yaitu (1) strategi Think Talk Write (TTW) efektif terhadap kemampuan pemecahan masalah matematis siswa pada materi bangun ruang sisi datar; (2) pendekatan saintifik tidak efektif terhadap kemampuan pemecahan masalah matematis siswa pada materi bangun ruang sisi datar; dan (3) terdapat perbedaan Keefektifan Strategi Think Talk Write (TTW) dengan pendekatan saintifik terhadap kemampuan pemecahan masalah matematis siswa.

\section{DAFTAR RUJUKAN}

Daryanto, D. (2014). Pendekatan Pembelajaran Saintifik Kurikulum 2013. Yogyakarta: Gava Media.

Hamdayama, J. (2014). Model dan Metode Pembelajaran Kreatif. Jakarta: Ghalia Indonesia.

Hamdayama, J. (2015). Metodologi Pengajaran. Jakarta: PT. Bumi Aksara.

Husna, M., \& Fatimah, S. (2013). Peningkatan Kemampuan Pemecahan Masalah dan Komunikasi Matematis Siswa Sekolah Menengah Pertama melalui Model Pembelajaran Kooperatif Tipe Think-Pair-Share (TPS). Jurnal Peluang, 1(2), 81-92.

Musfiqon, M., \& Nurdyansyah, N. (2015). Pendekatan Pembelajaran Saintifik. Sidoarjo: Nizamia Learning Center.

Ningsih, S. C. (2014). Efektivitas Model Pembelajaran Think-Talk-Write dalam Meningkatkan Komunikasi Matematis Mahasiswa Pendidikan Matematika. AKSIOMA: Jurnal Program Studi Pendidikan Matematika, 3(2).

Gunawan, R. G., \& Putra, A. (2019). Pengaruh Strategi Belajar Aktif Sortir Kartu Terhadap Kemampuan Pemecahan Masalah Matematis. Jurnal Cendekia: Jurnal Pendidikan Matematika, 3(2), 362-370.

Sopiany, H. N., \& Hijjah, I. S. (2016). Penggunaan Strategi TTW (Think-Talk-Write) dengan Pendekatan Kontekstual dalam Meningkatkan Kemampuan Pemecahan Masalah dan Disposisi Matematis Siswa MTsN Rawamerta Karawang. JPPM (Jurnal Penelitian dan Pembelajaran Matematika), 9(2). 
Yamin, M., \& Antasari, B. I. (2012). Taktik Mengembangkan Kemampuan Individual Siswa. Jakarta: Gaung Persada Press.

Yanuarta, L., Waluyo, J., \& Suratno, S. (2014) . Penerapan Model Pembelajaran Tipe Think Talk Write (TTW) Dengan Teknik Talking Stick Dalam Meningkatkan Karakter dan Hasil Belajar Ipa-Biologi Siswa. Jurnal Pancaran Pendidikan, 3(1), 69-78. 